ARTICLE

\title{
Craniofacial Indices of the Different Ecotypes of the Sahel Goat in Nigeria.
}

\author{
*1SHAWULU, J. C., and ${ }^{2}$ KWARI, H. D. \\ 1. Department of Veterinary Anatomy, University of Abuja, Nigeria. ${ }^{2}$. Department of Veterinary Anatomy, University of Maiduguri, Nigeria. \\ *Correspondence, james.shawulu@ymail.com; Tel: +2348027274872, +2347063345777
}

\section{SUMMARY}

This study was done to ascertain if differences occur in the craniofacial indices of the seven ecotypes of the Sahel goat and to determine if such indices would be used for identification. Though females of all the ecotypes had higher values than males in all indices analyzed, only the rima oris length showed significant difference $(P<0.05)$ of $11.53 \mathrm{~cm}$. It was thus concluded that at this time it is sufficient to recognize each ecotype based essentially on coat colour and to a limited extent on craniofacial indices like the rima oris length.

KEY WORDS; Sahel goat, Craniofacial indices, Nigeria, Ecotypes.

\section{INTRODUCTION}

The head is a superior part of the body and is by far the most important region by virtue of the location of some vital organs of the body (Olopade and Onwuka, 2003). Some important clinical indices that can be determined from the organs include ageing in the teeth, anemic state from the mucus membrane of the eye, general state of health from the wetness of the muzzle and salivary secretions, dehydration from sunken eyeballs and starvation from periorbital depressions (Peacock, 1996; Olopade and Onwuka, 2003). The head can also be used in describing animal species within and between breeds (Devendra and McLeroy, 1982; Gall, 1996). In goats, the dorsal profile of the skull is domed over the cranial cavity and slopes sharply caudally towards the nuchal plane and gently rostrally towards the nasal end (Dyce et al., 2002). Specific breed description using the horn, the ears, the legs, coat colour and adaptability is common (Devendra and McLeroy, 1982; Kwari et al., 2004).

The Sahel breed is one of the major breed of goats in West Africa. The ecotypes of the breed have been characterized into seven different sub-types based on coat colour (Kwari, 2001; Kwari et al., 2004). The essence of this work is to determine if craniofacial indices alone can be used as a possible identification protocol in classifying the Sahel goat ecotypes.

\section{MATERIALS AND METHODS}

A total of 144 heads of identified seven ecotypes of Sahel goat in Borno state, Nigeria were used in this study. The goats were clinically examined for their state of health and were identified using coat colour principally of Basic white, Basic brown, Basic black, White and Brown, Brown and Black, Black and White and mixed colours. A total of eight parameters including the weight of the animal, weight of the head, lengths of external nares, length of pinnae, palpebral fissure lengths, length of rima oris, distance between median canthi and the distance from the muzzle to the external protuberance, based on the description of Olopade and Onwuka, (2003, 2004) and Kwari (2001) were measured in each head.

The data collected were analysed using the Graphpad Instat ${ }^{\circledR}$ computer software for analysis of variance. All values were presented as mean \pm SD and compared at $5 \%$ level of significance.

\section{RESULTS}

The result showed that the white ecotype (Borno White Goat) weighed $13.67 \pm 2.44 \mathrm{~kg}$ much less than other ecotypes, the highest weighed 18.30 $\pm 1.91 \mathrm{~kg}$ in the black and white ecotype (Table I). All paired parameters showed asymmetry in all ecotypes. The rima oris length showed a significant value within and between ecotypes. The White and Brown ecotype had shorter distance between median canthi (9.83 \pm 
$0.89 \mathrm{~cm})$. Female animals had higher values than their male counterpart in all the parameters measured (Table II). The values for most of the parameters measured also increased simultaneously with age in all the ecotypes (Table III).

TABLE I: Mean values of craniofacial indices of the seven ecotypes of Sahel goat

\begin{tabular}{|c|c|c|c|c|c|c|c|c|c|c|c|}
\hline ECOTYPES & $\begin{array}{l}\text { WA } \\
\text { (Kg) }\end{array}$ & $\begin{array}{l}\text { WOH } \\
\text { (Kg) }\end{array}$ & $\begin{array}{l}\text { RENL } \\
(\mathrm{cm})\end{array}$ & $\begin{array}{l}\text { RENR } \\
(\mathrm{cm})\end{array}$ & $\begin{array}{l}\text { AURL } \\
(\mathrm{cm})\end{array}$ & $\begin{array}{l}\text { AURR } \\
(\mathrm{cm})\end{array}$ & $\begin{array}{l}\text { PFLL } \\
(\mathrm{cm})\end{array}$ & $\begin{array}{l}\text { PFLR } \\
(\mathrm{cm})\end{array}$ & $\begin{array}{l}\text { RO } \\
(\mathrm{cm})\end{array}$ & $\begin{array}{l}\text { DMC } \\
(\mathrm{cm})\end{array}$ & $\begin{array}{l}\text { DOCM } \\
(\mathrm{cm})\end{array}$ \\
\hline$B W n=24$ & $13.67 \pm 2.44$ & $1.13 \pm 0.45$ & $2.59 \pm 0.30$ & $2.59 \pm 0.32$ & $15.86 \pm 1.79$ & $16.46 \pm 1.20$ & $3.75 \pm 0.42$ & $3.88 \pm 0.26$ & $11.19 \pm 1.09$ & $10.14 \pm 0.88$ & $27.51 \pm 1.91$ \\
\hline$B B R n=20$ & $16.29 \pm 3.18$ & $1.19 \pm 0.19$ & $2.54 \pm 0.21$ & $2.58 \pm 0.20$ & $15.25 \pm 0.94$ & $15.07 \pm 1.67$ & $3.75 \pm 0.35$ & $3.82 \pm 0.34$ & $10.80 \pm 0.75$ & $10.00 \pm 1.20$ & $27.65 \pm 1.52$ \\
\hline BBK $n=20$ & $15.80 \pm 3.22$ & $1.26 \pm 0.08$ & $2.65 \pm 0.39$ & $2.57 \pm 0.40$ & $16.22 \pm 1.55$ & $15.78 \pm 1.73$ & $3.50 \pm 0.49$ & $3.81 \pm 0.44$ & $11.25 \pm 0.64$ & $10.70 \pm 1.29$ & $27.98 \pm 1.17$ \\
\hline$W B R n=20$ & $15.50 \pm 5.11$ & $1.16 \pm 0.06$ & $2.45 \pm 0.10$ & $2.49 \pm 0.14$ & $14.25 \pm 1.47$ & $13.99 \pm 1.46$ & $3.37 \pm 0.12$ & $3.94 \pm 0.28$ & $11.26 \pm 0.48$ & $9.83 \pm 0.89$ & $27.44 \pm 0.42$ \\
\hline$B A B n=20$ & $16.00 \pm 4.66$ & $1.26 \pm 0.08$ & $2.52 \pm 0.31$ & $2.57 \pm 0.36$ & $16.52 \pm 1.68$ & $16.65 \pm 1.23$ & $3.54 \pm 0.39$ & $3.65 \pm 0.45$ & $10.89 \pm 0.26$ & $10.12 \pm 1.02$ & $27.95 \pm 1.67$ \\
\hline WBK $n=20$ & $18.30 \pm 1.91$ & $1.36 \pm 0.10$ & $2.60 \pm 0.14$ & $2.61 \pm 0.11$ & $16.28 \pm 2.08$ & $16.52 \pm 2.02$ & $3.59 \pm 0.32$ & $3.81 \pm 0.40$ & $11.43 \pm 0.30^{\circ}$ & $10.13 \pm 0.51$ & $27.64 \pm 0.71$ \\
\hline$M I X n=20$ & $16.09 \pm 3.76$ & $1.22 \pm 0.21$ & $2.53 \pm 0.27$ & $2.58 \pm 0.31$ & $14.50 \pm 1.56$ & $14.03 \pm 1.58$ & $3.73 \pm 0.55$ & $3.93 \pm 0.66$ & $11.18 \pm 0.58$ & $10.21 \pm 0.97$ & $27.18 \pm 1.33$ \\
\hline
\end{tabular}

TABLE II: Mean values of craniofacial indices of ecotypes of Sahel goat based on sex differences

\begin{tabular}{|c|c|c|c|c|c|c|c|c|c|c|c|}
\hline ECOTYPES & $\begin{array}{l}\text { WA } \\
(\mathrm{Kg})\end{array}$ & $\begin{array}{l}\text { WOH } \\
\text { (Kg) }\end{array}$ & $\begin{array}{l}\text { RENL } \\
\text { (cm) }\end{array}$ & $\begin{array}{l}\text { RENR } \\
\text { (cm) }\end{array}$ & $\begin{array}{l}\text { AURL } \\
(\mathrm{cm})\end{array}$ & $\begin{array}{l}\text { AURR } \\
(\mathrm{cm})\end{array}$ & $\begin{array}{l}\text { PFLL } \\
(\mathrm{cm})\end{array}$ & $\begin{array}{r}\text { PFLR } \\
(\mathrm{cm})\end{array}$ & $\begin{array}{l}\text { RO } \\
(\mathrm{cm})\end{array}$ & $\begin{array}{l}\text { DMC } \\
(\mathrm{cm})\end{array}$ & $\begin{array}{l}\text { DOCM } \\
(\mathrm{cm})\end{array}$ \\
\hline BW & $12.67 \pm 1.37$ & $1.03 \pm 0.08$ & $48 \pm 0.33$ & $45 \pm 0.26$ & & $16.33 \pm 0.70$ & & & 1.18 & $10.05 \pm 0.48$ & \\
\hline$n=24 \quad F$ & $14.67 \pm 3.51$ & $1.23 \pm 0.18$ & $2.70 \pm 0.26$ & & & & & & & & \\
\hline & $14.00 \pm 2.00$ & & & & & & $3.70 \pm 0.20$ & & & & \\
\hline $\mathrm{n}=20 \quad \mathrm{~F}$ & $18.57 \pm 4.35$ & $1.21 \pm 0.20$ & & $2.66 \pm 0.22$ & & & & & \pm 0.83 & $10.50 \pm 1.09$ & 1.50 \\
\hline & $14.60 \pm 2.07$ & $1.23 \pm 0.09$ & $2.62 \pm 0.29$ & & & & & & & & 1.61 \\
\hline$n=20$ & $17.00 \pm 4.36$ & $1.28 \pm 0.07$ & $2.67 \pm 0.49$ & & $16.36 \pm$ & & & & \pm 1.16 & & \\
\hline & $12.00 \pm 1.73$ & $1.08 \pm 0.01$ & $2.30 \pm 0.20$ & $2.23 \pm 0.06$ & $13.20 \pm 0.42$ & $12.45 \pm 0.50$ & $3.60 \pm 0.17$ & $3.73 \pm 0.21$ & $11.00 \pm 0.46$ & $9.72 \pm 0.85$ & $27.27 \pm 0.70$ \\
\hline$n=20$ & $19.00 \pm 8.49$ & $1.23 \pm 0.11$ & $2.60 \pm 0.00$ & $2.75 \pm 0.21$ & 15.30 & 15.53 & 0.07 & $4.15 \pm 0.35$ & $11.51 \pm 0.50$ & $9.95 \pm 0.92$ & $=0.14$ \\
\hline & & & & & & & & & & & \\
\hline$n=20$ & $16.50 \pm 4.95$ & $1.28 \pm 0.11$ & $2.53 \pm 0.33$ & $2.63 \pm 0.30$ & $17.25 \pm 1.06$ & $17.50 \pm 0.57$ & $3.63 \pm 0.43$ & & $11.50 \pm 0.00$ & $10.28 \pm 0.84$ & \pm 2.70 \\
\hline WBK & $12.60 \pm 2.41$ & $1.17 \pm 0.14$ & $2.45 \pm 0.20$ & $2.36 \pm 0.14$ & & & & & & $9.56 \pm 0.59$ & $27.07 \pm 0.85$ \\
\hline$n=20$ & $24.00 \pm 1.41$ & $1.54 \pm 0.05$ & $2.75 \pm 0.07$ & $2.85 \pm 0.07$ & & $16.60 \pm 2.26$ & $3.90 \pm 0.28$ & & $12.55 \pm 0.07$ & $10.70 \pm 0.42$ & $28.20 \pm 0.57$ \\
\hline & & $1.09 \pm 0.21$ & $2.48 \pm 0.21$ & $2.57 \pm 0.40$ & & & & & $10.85 \pm 1.06$ & $10.13 \pm 1.07$ & $27.10 \pm 1.23$ \\
\hline$n=20$ & $18.67 \pm 6.51$ & $1.34 \pm 0.20$ & $2.57 \pm 0.32$ & $2.58 \pm 0.22$ & $15.57 \pm 1.37$ & $14.57 \pm 1.22$ & $3.83 \pm 0.76$ & $4.07 \pm 0.68$ & $11.50 \pm 0.10$ & $10.28 \pm 0.86$ & $27.25 \pm 1.43$ \\
\hline
\end{tabular}

$*=p<0.05, n=$ number of samples

WA=Weight of animal, WOH=Weight of head, RENL= Length of left external nare, RENR= Length of right external nare, AURL $=$ Length of left pinna, AURR=Length of right pinna, PFLL=Length of left palpebral fissure, PFLR=Length of right palpebral fissure, $R O=$ Length of rima oris, DMC=Distance between median canthi, $\mathrm{DOCM}=$ Distance between the muzzle and the external occipital protuberance, $\mathrm{M}=$ Male, $\mathrm{F}=$ Female

Fig. 1: A male Sahel goat head

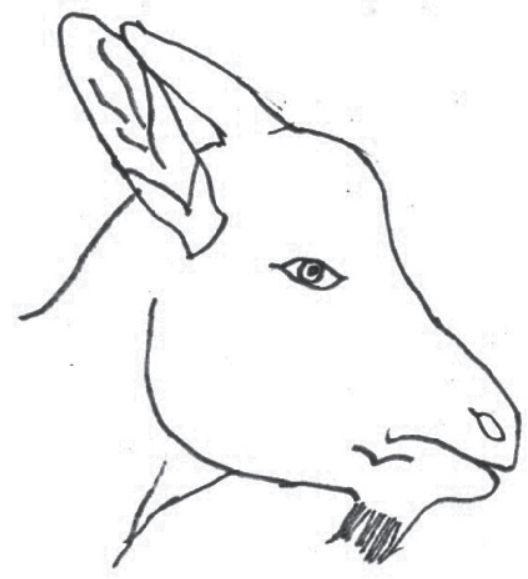

Fig. 2: A female Sahel Goat head

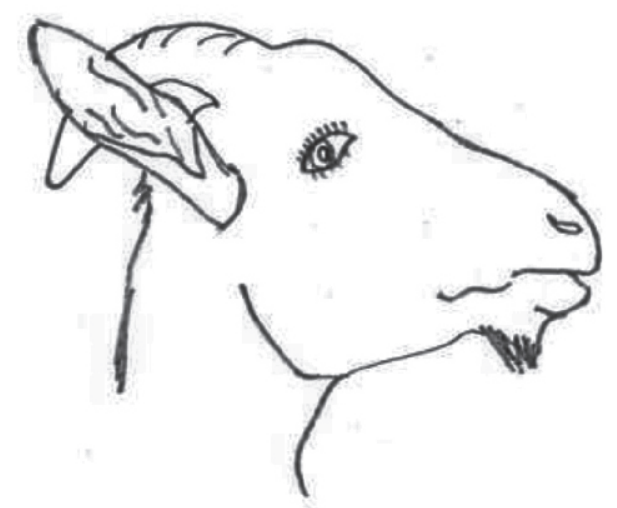


Shawulu and Kwari Craniofacial Indices of the Different Ecotypes of the Sahel Goat in Nigeria. 287 - 290

TABLE III: Mean values of craniofacial indices of the ecotypes of Sahel goat based on age.

\begin{tabular}{|c|c|c|c|c|c|c|c|c|c|c|c|}
\hline ECOTYPES & $\begin{array}{l}\text { WA } \\
(\mathrm{Kg})\end{array}$ & $\begin{array}{l}\text { WOH } \\
(\mathrm{Kg})\end{array}$ & $\begin{array}{l}\text { RENL } \\
(\mathrm{cm})\end{array}$ & $\begin{array}{l}\text { RENR } \\
(\mathrm{cm})\end{array}$ & $\begin{array}{l}\text { AURL } \\
(\mathrm{cm})\end{array}$ & $\begin{array}{l}\text { AURR } \\
(\mathrm{cm})\end{array}$ & $\begin{array}{l}\text { PFLL } \\
(\mathrm{cm})\end{array}$ & $\begin{array}{l}\text { PFLR } \\
(\mathrm{cm}) \\
\end{array}$ & $\begin{array}{l}\text { RO } \\
(\mathrm{cm})\end{array}$ & $\begin{array}{l}\text { DMC } \\
(\mathrm{cm})\end{array}$ & $\begin{array}{l}\text { DOCM } \\
(\mathrm{cm})\end{array}$ \\
\hline \multicolumn{12}{|l|}{ Bws } \\
\hline$\geq 6 \mathrm{~m}(\mathrm{n}=10)$ & $12.33 \pm 1.51$ & $1.01 \pm 0.06$ & $2.38 \pm 0.21$ & $2.38 \pm 0.23$ & $14.70 \pm 2.49$ & $16.22 \pm 1.60$ & $3.53 \pm 0.43$ & $3.75 \pm 0.26$ & $10.73 \pm 1.18$ & $9.92 \pm 0.69$ & $26.70 \pm 1.74$ \\
\hline$\geq \operatorname{lyr}(\mathrm{n}=7)$ & $14.00 \pm 1.41$ & $1.19 \pm 0.02$ & $2.90 \pm 0.14$ & $2.80 \pm 0.14$ & $17.50 \pm 1.41$ & $17.10 \pm 0.99$ & $4.25 \pm 0.35$ & $4.15 \pm 0.50$ & $11.40 \pm 0.28$ & $10.15 \pm 0.78$ & $28.25 \pm 1.06$ \\
\hline$\geq 2 y r(n=7)$ & $18.00 \pm 1.52$ & $1.43 \pm 0.09$ & $2.90 \pm 0.00$ & $3.00 \pm 0.00$ & $17.30 \pm 0.00$ & $17.00 \pm 0.00$ & $3.90 \pm 0.00$ & $4.00 \pm 0.00$ & $12.50 \pm 0.34^{*}$ & $11.20 \pm 0.79$ & $29.60 \pm 1.17$ \\
\hline \multicolumn{12}{|l|}{ BBR } \\
\hline$\geq 6 \mathrm{~m}(\mathrm{n}=10)$ & $14.20 \pm 1.48$ & $1.07 \pm 0.03$ & $2.52 \pm 0.13$ & $2.54 \pm 0.13$ & $15.00 \pm 0.31$ & $14.94 \pm 1.20$ & $3.68 \pm 0.35$ & $3.88 \pm 0.37$ & $11.14 \pm 0.92$ & $9.70 \pm 1.05$ & $27.22 \pm 1.20$ \\
\hline$\geq \operatorname{lyr}(\mathrm{n}=7)$ & $17.50 \pm 2.12$ & $1.25 \pm 0.14$ & $2.65 \pm 0.21$ & $2.60 \pm 0.42$ & $15.30 \pm 2.40$ & $15.00 \pm 3.00$ & $3.45 \pm 0.07$ & $3.50 \pm 0.57$ & $10.00 \pm 0.00$ & $9.95 \pm 1.49$ & $27.40 \pm 0.71$ \\
\hline $2 y r(n=7)$ & $22.00 \pm 4.36$ & $1.37 \pm 0.22$ & $2.60 \pm 0.44$ & $2.73 \pm 0.21$ & $14.83 \pm 1.19$ & $14.90 \pm 1.65$ & $4.13 \pm 0.45$ & $4.10 \pm 0.36$ & $11.40 \pm 0.66 *$ & $11.20 \pm 0.89$ & $28.93 \pm 1.85$ \\
\hline \multicolumn{12}{|l|}{ BBK } \\
\hline$\geq 6 \mathrm{~m}(\mathrm{n}=10)$ & $13.00 \pm 0.82$ & $1.21 \pm 0.06$ & $2.55 \pm 0.42$ & $2.38 \pm 0.44$ & $15.40 \pm 1.51$ & $14.80 \pm 1.60$ & $3.08 \pm 0.22$ & $3.38 \pm 0.25$ & $10.78 \pm 0.46$ & $9.85 \pm 0.93$ & $27.50 \pm 1.39$ \\
\hline$\geq \operatorname{lyr}(\mathrm{n}=7)$ & $16.50 \pm 2.12$ & $1.34 \pm 0.09$ & $2.50 \pm 0.14$ & $2.65 \pm 0.07$ & $17.10 \pm 0.85$ & $16.70 \pm 0.42$ & $3.90 \pm 0.14$ & $4.05 \pm 0.07$ & $11.15 \pm 0.71$ & $11.00 \pm 0.71$ & $29.30 \pm 0.28$ \\
\hline$\geq 2 y r(n=7)$ & $19.50 \pm 0.71$ & $1.28 \pm 0.04$ & $2.95 \pm 0.07$ & $2.85 \pm 0.07$ & $17.10 \pm 0.14$ & $16.95 \pm 0.07$ & $3.85 \pm 0.07$ & $4.25 \pm 0.07$ & $12.10 \pm 0.14^{*}$ & $11.95 \pm 0.07$ & $28.25 \pm 0.35$ \\
\hline \multicolumn{12}{|c|}{\begin{tabular}{|l|l|l|l|l|l|l|l|} 
WBR & & & & & & & \\
\end{tabular}} \\
\hline$\geq 6 m(n=10)$ & $12.00 \pm 1.73$ & $1.08 \pm 0.01$ & $2.30 \pm 0.20$ & $2.17 \pm 0.15$ & $15.30 \pm 2.52$ & $15.53 \pm 2.41$ & $3.60 \pm 0.17$ & $3.73 \pm 0.21$ & $11.00 \pm 0.46$ & $9.70 \pm 0.85$ & $27.26 \pm 0.70$ \\
\hline$\geq \operatorname{lyr}(n=7)$ & $19.00 \pm 8.49$ & $1.23 \pm 0.04$ & $2.60 \pm 0.00$ & $2.75 \pm 0.21$ & $13.20 \pm 0.42$ & $12.45 \pm 0.50$ & $3.85 \pm 0.07$ & $4.15 \pm 0.35$ & $11.51 \pm 0.50$ & $9.95 \pm 0.92$ & $27.60 \pm 0.14$ \\
\hline \multicolumn{12}{|l|}{ BAB } \\
\hline$\geq 6 \mathrm{~m}(\mathrm{n}=10)$ & $13.50 \pm 0.71$ & $1.19 \pm 0.16$ & $2.47 \pm 0.38$ & $2.60 \pm 0.36$ & $14.87 \pm 1.70$ & $15.37 \pm 1.77$ & $3.53 \pm 0.47$ & $3.63 \pm 0.40$ & $10.03 \pm 0.21$ & $10.03 \pm 0.84$ & $27.40 \pm 1.97$ \\
\hline$\geq \operatorname{lyr}(\mathrm{n}=7)$ & $16.00 \pm 0.20$ & $1.26 \pm 0.09$ & $2.50 \pm 0.28$ & $2.45 \pm 0.35$ & $17.50 \pm 1.41$ & $17.10 \pm 0.00$ & $3.55 \pm 0.50$ & $3.65 \pm 0.64$ & $11.25 \pm 0.35$ & $10.05 \pm 1.34$ & $28.10 \pm 1.56$ \\
\hline$\geq 2 y r(n=7)$ & $20.00 \pm 0.60$ & $1.35 \pm 0.11$ & $2.70 \pm 0.00$ & $2.80 \pm 0.00$ & $18.00 \pm 0.00$ & $17.90 \pm 0.00$ & $3.70 \pm 0.00$ & $3.90 \pm 0.00$ & $11.50 \pm 0.23$ & $10.80 \pm 1.28$ & $28.10 \pm 1.57$ \\
\hline \multicolumn{12}{|l|}{ WBK } \\
\hline & $12.60 \pm 2.41$ & $1.17 \pm 0.14$ & $2.45 \pm 0.20$ & $2.36 \pm 0.14$ & $16.25 \pm 1.75$ & $16.44 \pm 1.77$ & $3.28 \pm 0.35$ & $3.66 \pm 0.73$ & $10.31 \pm 0.53$ & $9.56 \pm 0.59$ & $27.07 \pm 0.85$ \\
\hline$\geq 2 y r(n=7)$ & $24.00 \pm 1.41$ & $1.54 \pm 0.05$ & $2.75 \pm 0.07$ & $2.85 \pm 0.07$ & $16.30 \pm 2.27$ & $16.60 \pm 2.26$ & $3.90 \pm 0.28$ & $3.95 \pm 0.07$ & $12.55 \pm 0.07$ & $10.70 \pm 0.42$ & $28.20 \pm 0.57$ \\
\hline \multicolumn{12}{|l|}{ MIX } \\
\hline $36 \mathrm{~m}(\mathrm{n}=10)$ & $12.50 \pm 0.00$ & $1.09 \pm 0.21$ & $2.48 \pm 0.21$ & $2.56 \pm 0.22$ & $13.45 \pm 1.75$ & $13.48 \pm 1.93$ & $3.63 \pm 0.33$ & $3.78 \pm 0.63$ & $10.85 \pm 1.06$ & $8.90 \pm 1.07$ & $25.70 \pm 1.23$ \\
\hline$\underline{\underline{z}} \operatorname{lyr}(\mathrm{n}=7)$ & $13.50 \pm 0.00$ & $1.13 \pm 0.20$ & $2.20 \pm 0.00$ & $2.10 \pm 0.00$ & $16.50 \pm 0.00$ & $15.90 \pm 0.00$ & $3.00 \pm 0.00$ & $3.30 \pm 0.00$ & $11.60 \pm 0.10$ & $10.28 \pm 0.86$ & $27.25 \pm 1.43$ \\
\hline$\geq 2 y r(n=7)$ & $22.00 \pm 4.24$ & $1.45 \pm 0.11$ & $2.75 \pm 0.07$ & $2.80 \pm 0.00$ & $15.10 \pm 1.56$ & $13.90 \pm 0.57$ & $4.25 \pm 0.35$ & $4.45 \pm 0.21$ & $11.45 \pm 0.07$ & $10.75 \pm 0.07$ & $27.80 \pm 0.28$ \\
\hline
\end{tabular}

$*=p<0.05, n=$ number of samples

\section{DISCUSSION}

The craniofacial study of all the seven ecotypes of the Sahel goat suggests a close morphological relationship with the westward and southward breeds of goats in Nigeria. This is probable that the Brown ecotype must have resulted from a crossbreeding with the Kano brown and Red Sokoto breeds while the black ecotype evolved from crossbreeding with the southward West African dwarf (WAD) breed. All ecotypes were slender and long legged and weighed on the average $13.55 \mathrm{~kg}$ in males which was significantly $(\mathrm{P}<0.05)$ lower than that of the females. This significance (sex based weight difference) occurred across all the ecotypes. The body weight of Sahel goat increased relatively with increase in age in all ecotypes. The average body weight obtained in this study compares favorably with the $13.30 \mathrm{~kg}$ and $18.60 \mathrm{~kg}$ for male and female Red Sokoto goats (Olopade and Onwuka, 2003). However, the head weight of $1.15 \mathrm{~kg}$ and $1.29 \mathrm{~kg}$ was well above the $0.74 \mathrm{~kg}$ and $0.90 \mathrm{~kg}$ of Red Sokoto and West African dwarf respectively (Olopade and Onwuka,
2003; 2004). Similarly, the palpebral fissure lengths which ranges between $3.57 \mathrm{~cm}-3.94 \mathrm{~cm}$ was far longer than the $2.50 \mathrm{~cm}$ of Red Sokoto goats and $2.14 \mathrm{~cm}-2.16 \mathrm{~cm}$ for West African dwarf (WAD) reported by Olopade and Onwuka, $(2003 ; 2004)$ respectively and as represented in figs (1\&2). There was no significant difference $(\mathrm{P}>0.05)$ amongst the Sahel ecotypes for the above named indices. The length of rima oris in Sahel goat increased with age in all ecotypes. Also, a significant difference was found in the length of rima oris across the ecotypes $(\mathrm{P}<0.05)$. This may have a direct correlation to the prehensile and feeding patterns and habits of animals in the semi-arid regions. There was no significant difference $(P>0.05)$ between the lengths of the external nares of the ecotypes of the Sahel goat though females generally had longer external nares than males. The distance between the media canthi (DMC) and the lengths of the external ears (pinnae) did not show any significant difference between the ecotypes nor within the sexes in each ecotype. A slight asymmetry was observed in all ecotypes 
and between sexes in the values of external ear lengths, palpebral fissure lengths and external nares lengths as reported by Sisson and Grossman, (1975) and Olopade and Onwuka, (2004). The acting force for breed development may be geographic isolation alone or combined with man's decision. In the Borno pastoral setting in Nigeria, cross breeding amongst the seven ecotypes as described by Kwari et al. (2004) is indiscriminate. While slight differences were observed among the ecotypes, few were significant and thus insufficient in many instances to get a leading physical index especially on the head. The evolving variations in craniofacial characteristics within these ecotypes are probably as great as between the Sahel breed and its western (Kano Brown and Red Sokoto) and southern (West African Dwarf) neighbors. At this time, it is thus sufficient to recognize each based essentially on coat colour and in a limited sense, craniofacial indices like the rima oris length that showed statistical significance.

\section{REFERENCES}

DEVENDRA, C. AND MCLEROY, G. L. (1982): Goats. In: Goat and sheep production in the tropics. Longman, London, 11-16.

DYCE, K. M., SACK, W. O. AND WENSING, C. J. G.
(2002): Textbook of Veterinary Anatomy, $3^{\text {rd }}$ edition Philadelphia, W.B. Saunders Company.

GALL, C. (1996): Goat breeds of the world, Centre for Tropical Agriculture, Weikersheim: Margraf, 4769.

KWARI, H. D., SIVACHELVAN, M. N. AND CHIBUZO, G.A. (2004): Cheracterization of Sahel goat in Borno State, Nigeria for certain qualitative traits. Nig. J. of Exp. and Appl. Biology. 5, 2:151-154.

KWARI, H. D. (2001): Morphological study of the ecotypes of Sahel goats in Borno state with special reference to Sexual dimorphism: $\mathrm{PhD}$ thesis, Department of Veterinary Anatomy, University of Maiduguri, Nigeria.

OLOPADE J.O AND ONWUKA S. K. (2004): Morphometric studies of the craniofacial region of the West Africa Dwarf goat in Nigeria. Int. J. Morphol., 22(2):145-8.s

OLOPADE, J. O. AND ONWUKA, S. K. (2003): A preliminary investigation into the aspect of some cranio-facial indices of the Red Sokoto (maradi) goat in Nigeria. Folia veterinaria. 47, 2:57-59.

PEACOCK C. (1996): Improving goat production in the tropics. A manual for development workers, Farm-Africa (editor) $5^{\text {th }}$ edition, WB. Saunders Company, Philadelphia.

SISSON, S. AND GROSSMAN, D. (1975): The Anatomy of the domestic animals. R. Getty (editor) $5^{\text {th }}$ edition, WB. Saunders Company, Philadelphia. 